
\title{
28 Research Square \\ La Vida de Juan: A Cost-Benefit Analysis of Crime and Violence in Mexico
}

\author{
Arturo Cervantes Trejo \\ Universidad Anáhuac \\ Roey Ringel ( $\nabla$ roeyringel@gmail.com ) \\ Universidad Anáhuac \\ Isaac Deneb Castañeda Alcántara \\ Universidad Anáhuac \\ Isaac Baley Amiga \\ Universidad Anáhuac \\ Nicole Terrein De La Cruz \\ Universidad Anáhuac
}

\section{Research Article}

Keywords: Mexico, Crime, Violence, Inequality, Youth, Social Determinants of Health

Posted Date: February 7th, 2022

DOI: https://doi.org/10.21203/rs.3.rs-1321712/v1

License: (c) (i) This work is licensed under a Creative Commons Attribution 4.0 International License.

Read Full License 


\section{Abstract}

Background: Crime and violence have hindered the development of the people, economy, and health of Mexico. In this study, we conducted a cost-benefit analysis to illustrate the compounding costs associated with not addressing the risk factors that lead children and young persons to violence and crime in Mexico.

Methods: We created a fictional account of a typical male criminal offender in Mexico based on quantitative and qualitative data. Using quantitative and qualitative data from public, private, and government sources, we calculated the cost of each stage of Juan's life along with the total cost of all crimes, violence, and events until the age of 37.

Results: Direct and indirect costs increased exponentially over time as violent actions and crimes became more severe. The stage where costs were lowest was infancy, totaling \$6,216 USD, while the costliest stage was adulthood totaling $\$ 1,034,847$ USD. The total cost associated with the offender's life (up to age 37) was $\$ 1,752,501$ USD, while the total estimated cost of implementing prevention programs in each stage of life was $\$ 144,254$ USD.

Conclusions: The Mexican government must prioritize implementing evidence-based policies and programs for mitigating the risk factors that lead young persons to a life of violence and crime. Specifically, investing in programs at the earliest stages of life has been shown to have the greatest benefit in offsetting the compounding associated costs later in life. Our study shows that, theoretically, for every dollar invested on interventions to support Juan's life, \$12 are saved. This study can be used as an example and recommendation for other countries in Latin America and the Caribbean, which suffer from similar levels of violence and crime, and from similar cultural and socioeconomic conditions.

\section{Background}

Over the past decade substantial progress has been made to stop violence and crime around the world [1]. However, the Mexican government has yet to develop an effective, evidence-based strategy to combat the rampant violence and crime in the country, or to improve the underlying social and economic conditions that drive these issues [2]. Consequently, Mexico still ranks among the lowest in public security, and highest in rates of homicide and violent crime victimization globally. According to the latest data, Mexico has a homicide rate of 29 deaths per 100,000 people, almost 8 times higher than the homicide rates of OECD countries, which average 3.7 per 100,000, and the highest of all OECD countries $[1,3]$. Additionally, $30.6 \%$ of individuals in Mexico were victims of crime in 2020 , statistically significantly higher than the average criminal victimization rates of 30 countries included in the International Crime Victims Survey [4]. This is further illustrated by the fact that in 2020, there were over 21.2 million crimes committed in Mexico to persons 18 years and older, $41.6 \%$ of which involved the use of a weapon [5].

According to Mexico's National Institute of Statistics and Geography (INEGI) national census, Mexico had a population of 126 million people in 2020, of which 38.2 million are under the age of 18 [6]. Recent 
analyses have shown that $43.9 \%$ of the total population, including $52.6 \%$ of those under 18 years old and $54.3 \%$ of infants under 6 years old live in poverty in Mexico [7]. Since 2018, the percentage of those living in extreme poverty has risen from $7.0 \%$ to $8.5 \%$, and those lacking access to healthcare has increased from $16.2 \%$ to $28.2 \%$ [8]. Furthermore, according to recent estimates, the high levels of crime and violence in Mexico have directly cost the country $\$ 221$ billion USD in 2020, and have substantially hindered the development and health of the country, its economy, and its people [9].

In order to illustrate the relationship between various developmental risk factors over a lifetime, and the cost of violence and crime in Mexico, "La Vida de Juan" was created. This story was inspired by Public Safety Canada's "Tyler's Troubled Life", a landmark study that mobilized the Canadian government towards investing in crime prevention [10]. Juan's life story is a fictional narrative that illustrates the compounding economic and social costs of a typical young man exposed to multiple forms of violence from infancy and through childhood and adolescence, which lead him to become a chronic criminal offender. The story illustrates how his criminal outcomes were influenced by individual, family, and community risk factors, as well as from the socioeconomic determinants which lead him down a path of violence and crime. This narrative is based on real events and was developed from both qualitative and quantitative information describing the prevalence of diverse types of violence and criminal behaviors observed in Mexican youth. It seeks to reveal the economic and social consequences that arise from neglecting to address the fundamental risk factors that lead individuals to a life of violence and crime.

Juan's story is presented through six life stages; infancy ( 0 -2 years), preschool (3-5 years), school age (610 years), young adolescence (11-14 years), late adolescence (15-17 years), and adulthood (18 - 37 years). Each life stage depicted has unique risk factors that influence Juan's behaviors and violent actions, and represent an opportunity where an evidence-based intervention could have changed the course of his life. The aim of our study is to illustrate the costs of leaving the known predisposing or risk factors for violence and crime unaddressed over the course of a typical young offender's lifetime, and to present the potential benefits of employing evidence-based interventions at key stages of development. Our aim is that Juan's life story can serve as an example not only for necessary changes in Mexico, but for other Latin American and Caribbean countries who suffer from similar levels of violent crime and homicide -together accounting for $37 \%$ of homicides globally [11].

\section{Methods}

\section{Study Design}

We developed Juan's life story based on a variety of qualitative and quantitative sources that provide insight into the risk factors, predisposing conditions, and impact of crime and violence in Mexico. Qualitative research included field work conducted under the auspices of the Mexican Ministry of Health's National Council for Injury Prevention (CONAPRA), in Ciudad Juarez, Chihuahua during 2007 and 2014. We also reviewed life stories documented and reported by newspapers and local media, as well as 
interviews with non-governmental organizations working with disadvantaged youth in high risk neighborhoods and criminal offenders.

The estimates of Juan's exposure to violence and criminal behavior, and the specific types of crimes committed during the various life stages, were based on a survey conducted by our group at 14 Mexican Federal Prisons (CEFERESOS) during 2018, which included 3,419 incarcerated male respondents. Information on prevalence and incidence of violence, delinquency, and criminal victimization, was based on the National Crime Victimization Survey (ENVIPE 2021) and National Crime Business Victimization Survey (ENVE 2020) [5,12].

It is worth noting that the number and severity of criminal actions reported during Juan's life, and their associated costs, may be considerably underestimated due to the impunity rates observed in the country, evidenced by the fact that over $93.3 \%$ of all crimes in Mexico are left unreported [5]. Total cost savings from each age-stage-specific intervention were calculated by subtracting the costs of the interventions from the total estimated cost of the consequences of violence and crime in Juan's life. This calculation was conducted under the assumption that successfully implemented interventions will lead to a halt in all subsequent crimes and consequences of violent acts.

\section{Cost Data}

The individual costs of the consequences of each of the violent, delinquent, and criminal events in Juan's life were estimated from various official sources of information. These include INEGI's National Survey of Business Victimization (ENVE 2020), the National Survey of Victimization and Perception of Public Safety (ENVIPE 2021), the Childhood and Family Welfare Agency (DIF for its Spanish acronym "Sistema Nacional para el Desarrollo Integral de la Familia"), the Mexican Institute of Social Security (IMSS), and international sources including the Institute of Medicine's publications regarding the lifetime cost of violent episodes (USA). Average costs are categorized into groups including: health care, policing and justice administration, different violent acts, private security, auto part theft, intervention programs, and education. Each of these categories were used to calculate the total cost of Juan's life until the age of 37.

The costs were calculated in Mexican pesos based on prices published by the aforementioned institutions. Costs reported prior to 2021 were converted to the value of the Mexican peso for 2021, using inflation calculation tools [13]. Prices were then converted to United States Dollars (USD) using the November 2021 exchange rate. The breakdown of each cost and its source is presented in the supplement.

\section{Costs and Proposals for Interventions}

Evidence based interventions were chosen based on proven effectiveness (per specific age group) and strength of outcomes in published literature. The costs of the interventions were provided by published 
literature and local organizations implementing these programs in Mexico and other Latin American countries. These costs are representative of the price of implementation per one family or individual, depending on the intervention.

Given that the cost of the interventions is not exact, some of the costs are averages from multiple sources. Additionally, given that our high-risk population may require more resources than usually necessary, we have doubled the estimated cost of all of the interventions in our analysis, other than for the Progresa program, to cover any inaccuracies.

\section{Juan's Story}

Juan represents a typical Mexican child born into a troubled family, who must cope with socioeconomic disadvantage, poverty, family violence, and neglect. As he grows up, he continues to be affected by the risk factors in his home and community. Consequently, he lives a childhood full of conflict and exposure to violence and crime, which ultimately lands him in prison. Juan's experiences are used to highlight the most common risk factors that affect Mexican youth who become involved in crime, and his life path represents one of many possible outcomes commonly seen in adolescent offenders. His narrative illustrates the compounding costs associated with neglecting to address the risk factors that lead children and young persons to violence and crime in Mexico. This is his story:

\section{Stage: Infancy (0-2 years old)}

Juan's mother was raised by her grandmother after her parents abandoned her at a young age. She became pregnant in her last year of high school and while her boyfriend (Juan's father) supported her for a short time, he left Juan's mother shortly before Juan was born [14]. During her pregnancy, and in the first 7 months of Juan's life, Juan's mother found work by taking care of the neighbor's children. During these first months, Juan attended a nursery. However, due to low vaccination rates in the community, Juan contracted influenza pneumonia and was admitted to the hospital for 5 days $[15,16]$.

Juan's father would appear occasionally to give Juan's mother some money. However, on one visit, he got into an argument with Juan's mother and an episode of domestic violence ensued, causing a neighbor to call the police [17]. The police detained Juan's father and discovered that he was wanted for robbery. He was subsequently sent to prison for 2 years. After this incident, the police reported Juan to the DIF. A few months later, after being notified of his admission to a pediatric hospital for acute gastroenteritis, the DIF carried out an investigation which found that Juan was exposed to a high-risk environment, low quality of care, and lack of adequate attention [18]. Juan's mother was advised to participate in a support program for women. Juan's mother attended this support group for a few months, but later stopped because it was incompatible with her need to work to sustain her family. Juan's grandmother died when Juan was one year old. Unable to cover rent, Juan and his mother went to live with Juan's aunt in a small apartment along with her 3 children. 


\section{Stage: Preschool (3-5 years old)}

Life in the apartment was difficult for both Juan and his mother. His uncle was an alcoholic who physically abused his two children, his partner, and Juan [19]. In one case of abuse, Juan was brought to the hospital for an eyebrow wound which required suturing. During this difficult stage of life, Juan developed a hostile attitude and aggressive behavior. He bit his cousins and classmates on several occasions, even sending two children to the doctor.

After leaving prison, Juan's father took Juan and his mother to live with him in an apartment in a socioeconomically disadvantaged neighborhood. Juan had to be transferred between several different daycares because of his aggressive and antisocial behavior, and eventually he was refused admission to daycare. Juan's mother became pregnant again with Juan's father. While Juan's mother went to work, Juan's father took care of him at home. Juan's father brought him to and from the nearby public kindergarten, but one day he had a fight with the director of the kindergarten leading to Juan's expulsion.

Juan's father found a new partner, and began to neglect Juan and his mother. One day, he hit Juan's mother so hard that she had to go to the hospital [17]. When she returned, Juan's father had left. Juan and his mother found out that Juan's father was once again in prison-this time for selling drugs and robbery [20]. A few days later, the police arrived at the apartment with a search warrant. In the apartment, they found narcotics, stolen objects, and a gun, for which Juan's mother was arrested and sent to prison.

Juan's aunt decided that Juan should return to live in her house. During his stay, Juan was sexually abused by his uncle, which he never told anyone about [21]. Neighbors who knew about the domestic violence and abuse that took place in the house reported it to the authorities and Juan was sent to a DIF orphanage.

\section{Stage: School age (6-10 years old)}

With his mother and father in prison, Juan lived in the DIF orphanage until he was 8 years old [22]. At the orphanage's school, Juan was the source of many disruptions. On one occasion when he attacked his classmate with a rock, the child had to be hospitalized and underwent surgery for a head injury. The school psychologist then referred Juan to a psychiatrist who diagnosed him with disruptive mood dysregulation disorder [23]. He subsequently entered a support program in which he received therapy and medications. Despite this support, Juan fell behind in school, had to repeat a school year, and continued his violent behavior. On one particularly bad day, Juan broke two chairs, a table, a window, and a television, leading to his expulsion from the orphanage, and abrupt cessation of medical treatment and education. Juan, now without any support, lived on the street [24]. He often stole items from supermarkets and self-service stores to survive. Juan also sold sweets and cleaned cars, in addition to being involved in the theft of auto parts to get by. 


\section{Stage: Young Adolescent (11 - 14 years old)}

Living on the streets, Juan met a gang of adolescents and young adults who also lacked parents or any other form of support [25]. As a member of this new group, Juan became involved with selling and using drugs, and committed armed robbery on eight separate occasions. Juan was arrested and taken to the police station, but was released without charges [26]. On the street he learned to fight, which earned him respect from others and a job as a messenger for drug dealers. However, on one occasion, he was attacked and robbed of his money and drugs by clients who left him badly injured. Bystanders called an ambulance, and he was transferred to the emergency service where he was treated for multiple wounds in both his arms and legs.

During his time living on the streets, Juan lost contact with his mother, but not with his father, who gave him some money and began to involve him in illicit activities, such as pirating CD's, drug trafficking, and extortions.

\section{Stage: Late Adolescent (15-17 years old)}

One night at a neighborhood party, with gang members, drugs, and alcohol, Juan raped a young girl [17]. She became pregnant, had a miscarriage, was hospitalized for two days, and was taken to a support group for raped girls. At the same party, he got into an argument and hit another boy, who ended up in intensive care for multiple fractures. Juan fled, and although days later he was apprehended by the police, the boy's family withdrew the complaint due to threats from other criminals who were protecting him. Juan soon became involved in major criminal activities such as car robbery, kidnapping, and homicide. He was caught in some acts, but always managed to escape thanks to bribes and the help of his protectors.

Juan formed his own gang with other young people who shared similar life stories as him. Together they began selling drugs, participated in the robberies of thirteen cars, and conducted a kidnapping of a local business owner for ransom [5]. During this time, Juan and his group started a fight over the distribution of drugs in their neighborhood, which eventually led to an armed confrontation, in which two rival gang members were shot and killed.

Juan also had many romantic partners, who admired him for his position of power on the street. He fathered a son with one of these partners, but was not involved in his life and offered them no financial support. Juan also beat his uncle in revenge for the physical and sexual abuse he suffered in his childhood, sending his uncle to the hospital for three days with multiple injuries. At this point, Juan had become completely estranged from his father, mother, and rest of his family aside from his younger brother.

\section{Stage: Adulthood (18 years old and onwards)}


As part of the largest drug distribution group in the city, Juan was involved in the trafficking of drugs between major cities. His brother, who was part of Juan's group, was killed during a police raid while conducting an illegal operation. Months later, together with his collaborators, Juan took revenge, and killed one of the gang members thought to be implicated in his brother's death.

During one of the drug transfers, Juan was caught, arrested, and sentenced to twelve years in prison. In prison, he served as a link between another criminal organization and his own group, becoming involved in seven kidnappings for ransom [27]. During his stay in prison, Juan was also involved in many fights, and in one of these, a prisoner died, with three others getting seriously injured. The injured prisoners were taken to the hospital for medical attention, along with two others with minor injuries, including Juan. In the aftermath of the fight, Juan was transferred to a high security prison and his sentence was extended for 7 more years.

Over the course of the following 5 years, eight members of his group were arrested, another two were killed on Juan's orders, and three were killed in clashes with other gangs. Today, Juan is 37 years old and is about to finish his prison sentence.

\section{Results}

The table below corresponds to the costs of neglect, violence, and crime related events throughout the different stages of Juan's life. The results of our study illustrate the direct and indirect costs associated with Juan's life, a life full of individual, family, and community risk factors. The costs of growing up in this type of environment increases exponentially with time as violence related actions and crimes become increasingly serious. The stage of Juan's life that cost the least was his infancy at $\$ 6,216$ USD while the costliest stage was adulthood at $\$ 1,034,847$ USD. Over the course of his life, Juan committed a total of six homicides, eight armed robberies, and eight kidnappings, among other crimes. Most of the more violent and serious crimes committed happened after 11 years of age.

\section{Table 1: Costs by Stage of Life}


Stage: Infancy ( $0-2$ years old)

Fact Event

Total Cost

1 Daycare (7 months)

$\$ 2,412$

2 Hospitalization for Pneumonia

$\$ 2,398$

Cost per bed per day ( 5 days) in hospitalization $\$ 463.60$ USD

Cost per X-ray (3 tests) \$18.00 USD

Cost of laboratory testing (2 tests) $\$ 5.05$ USD

Medication cost \$15.95 USD

3 Police call

$\$ 56$

$4 \quad$ Hospitalization for Gastroenteritis

Cost per bed per day in hospitalization $\$ 463.60$ USD

Cost of laboratory testing $\$ 5.05$ USD

5 DIF Investigation

$\$ 272$

6 Support Program for Women

Program cost per day $\$ 114.00 \mathrm{MXN}$

Total Cost of Juan's Infancy ( $0-2$ years old)

$\$ 6,216$

Stage: Preschool (3-5 years old)

Fact Event

Total Cost

7 Hospital care for Eyebrow Injury

$\$ 56$

Cost of care in the emergency room $\$ 33.55$

Cost of wound care $\$ 23.40$

8 Hospital care for two people due to bite

Cost of care in the emergency room $\$ 33.55$

Cost of wound care $\$ 23.40$

9 Daycare

$\$ 2,757$

Daycare cost $\$ 344.65$ per month

10 Lost Cost of Parent Without Income

Minimum wage in Mexico $\$ 7.08$

11 Search Warrant

Based on the salary of a police officer $\$ 800.00$ 
12 Orphanage (18 months)

$\$ 18,531$

13 Rape (Estimated lifelong cost per victim)

$\$ 34,150$

14 Police Call $\$ 56$

Total Cost of Juan's Preschool Stage (3-5 years old)

$\$ 56,814$

Stage: School age (6-10 years old)

Fact Event

Total Cost

15 Orphanage (4 months)

$\$ 4,118$

16 Hospital cost for assault

$\$ 56$

Cost of care in the emergency room $\$ 33.55$

Wound dressing cost $\$ 23.40$

17 Psychologist, Psychiatrist and Medications

Psychologist consultation cost $\$ 66.20$

Psychiatry consultation cost $\$ 115.45$

Cost of medications $\$ 42.10$

18 ADHD Therapy Program

$\$ 1,589$

Cost per therapy session $\$ 66.20$

19 Repeating School Year

$\$ 2,708$

20 Auto Parts Theft

Cost of a headlight of an average car $\$ 409.45$

Cost of a wheel of an average car $\$ 481.50$

Cost of a mirror of an average car $\$ 100.85$

Cost of a front emblem of an average car $\$ 73.15$

$21 \quad$ Home Disturbances

$\$ 1,124$

22 Robbery per business (Average)

$\$ 1,772$

Total Cost of Juan's School Stage (6-10 years old)

$\$ 68,620$

Stage: Young adolescent (11 - 14 years old)

Fact Event

Total Cost

23 Armed Robbery (8x)

$\$ 11,897$

Average cost of a robbery to a victim $\$ 1487.13$ 
25 Ambulance transportation and hospitalization

Cost ambulance transportation to a second level hospital \$354.65

Cost of care in the emergency room in a second level hospital $\$ 68.25$

Wound care $\$ 23.40$

\section{Piracy}

According to Forbes Mexico, piracy cost the Mexican economy 236 billion pesos a year in 2016.

\section{Extortions of Businesses (57x)}

Average cost per extortion of a business $\$ 224.80$

\section{Rape}

29 Support Program for Raped Women

Program cost per day $\$ 5.70$

Total Cost of Juan's Young Adolescent Stage (11 - 14 years old)

Stage: Late Adolescent (15-17 years old)

Fact Event

30 Hospitalization: Intensive Care

Cost per day in intensive care $\$ 2,207.55$

Cost per bed per day in hospitalization $\$ 463.60$

31 Police Apprehension

32 Car Robbery (13x)

Average cost of car theft $\$ 8,941.45$

\section{$33 \quad$ Kidnapping}

Average cost of kidnapping $\$ 18,864.82$

34 Homicides (2x)

The economic cost of a life is estimated to be $\$ 176,593$

35 Uncle's Hospitalization

Cost per bed per day of hospitalization $\$ 463.60$

Cost of Computed Axial Tomography $\$ 139.00$

Cost of non-laboratory testing $\$ 10.3$ 
Cost of laboratory tests $\$ 5.05$

Cost rehabilitation session $\$ 141.55$

Total Cost of Juan's Late Adolescent Stage (15-17 years old)

$\$ 502,627$

Stage: Adulthood (18 years old and over)

Fact Event

Total Cost

$36 \quad$ Homicide

$\$ 176,593$

The estimated economic cost of a life is $\$ 176,593$

37 Criminal Trial

$\$ 854$

Cost of a trial $\$ 823.30$

Cost of public defense $\$ 30.70$

$38 \quad 12-Y e a r$ Prison Sentence

$\$ 60,290$

Cost per day of a prisoner $\$ 13.75$

$39 \quad$ Kidnapping (7x)

$\$ 132,053$

Average cost of kidnapping $\$ 18,864.82$

40 Homicide

$\$ 176,593$

The estimated economic cost of a life is $\$ 176,593$

41 Ambulance Transportation and Hospitalization

$\$ 1,522$

Cost ambulance transportation to a second level hospital \$354.65

Cost of care in the emergency room in a second level hospital \$68.25

Wound care $\$ 46.80$

42 Criminal Trial

$\$ 854$

Cost of a trial $\$ 823.30$

Cost of public defense $\$ 30.70$

43 Cost of a seven-year sentence in a maximum-security prison

$\$ 63,875$

Cost per day per intern $\$ 25.00$

44 Cost of two homicides

The estimated economic cost of a life is $\$ 176,593$

$45 \quad$ Not Generating Income for 19 years

Minimum wage in Mexico $\$ 8.64$

Total Cost of Juan's Adulthood Stage (18 years old to 37 ) 
The above costs associated with violence and crime in Juan's life were then compared to the cost of implementing interventions at key points in his life. We chose to arrange these different stages of opportunity for intervention into four main blocks; Infancy (0-2), Preschool Until Early Teen (3-14), Late Adolescence (15-17), and Adulthood (18+). A comparison of the direct and indirect costs, and the cost of evidence-based interventions of each stage is available in Figure 1. It is important to note that the total cost of intervention reflects both the intervention itself, and the number of years over which the intervention is implemented. For example, the Preschool Until Early Teen stage covers twelve years, while Infancy covers two years.

During infancy (0-2), Juan is exposed to the following risk factors: having a young single mother, poverty and socioeconomic inequality, child abuse, and exposure to community infections. In order to help minimize the risk factors at this stage of Juan's life and steer him away from a life of crime, evidencebased interventions such as perinatal home visitation programs and early childhood development programs that reduce child abuse and neglect could have been implemented. These programs support new parents by improving infant caregiving skills, teaching parents how to feed infants and manage their crying, and how to encourage healthy childhood development. Studies have shown that home nurse visitations for at-risk mothers in the first two years of a newborn's life substantially reduced the likelihood of the child running away from home, getting arrested, being convicted of a crime, and violating probation later in life [28]. There are several organizations in Mexico already conducting similar interventions, for example, Compañeros en Salud (Partners in Health) has been conducting home visitation programs with trained volunteers in the region of Chiapas [29]. These organizations should be further supported and their programs expanded in order to provide care for families in need. Importantly, the cost of implementing such a program per individual is only $\$ 800$ while the total direct and indirect costs associated with Juan's life at this stage are $\$ 6,216$ [30]. Additionally, only an estimated $34.3 \%$ of children in Mexico are fully vaccinated, so efforts to fully vaccinate infants must be reinforced in order to reduce the spread of community acquired infections [16].

From preschool to his early teen years (3-14) Juan's unaddressed risk factors include: aggressive behavior, frequent home transitions, sexual abuse, substance abuse, lack of a nurturing and safe home environment, and criminal activity among his parents and peers, among others. To address these risk factors, cognitive-behavioral therapy (CBT) interventions could be introduced. CBT therapy helps individuals improve self-control, social skills, and decision making. One example of a cognitive-behavioral therapy program in Mexico is offered by Fundación Paidi, an organization implementing such interventions for children between the ages of 3 and 17 [31]. The total cost of violence and crime in Juan's life amounts to $\$ 207,295$ USD, while the cost of implementing a cognitive-behavioral intervention program in Mexico for one individual is around \$2,830 USD for 60 hours of treatment over the course of 4 months (considered typical). 
Juan's late adolescent years (15-17) are plagued by known risk factors such as unemployment, substance abuse, and engagement in criminal activity. At these later stages it becomes increasingly difficult to address the challenges presented in Juan's life since, as a chronic criminal offender, he is no longer in a structured, easily accessible environment such as school, but rather living on the street. To address the risk factors in Juan's life at this stage, effective interventions such as Multisystemic Therapy (MST) can be utilized. The goal of MST is to reduce criminal behavior in juvenile offenders by providing them with the necessary tools to mitigate problems such as: inattention, lack of discipline, problems at home, unhealthy relationships with peers, and school dropout. There are several organizations in Mexico already applying such programs with youth such as CEMEPI and R\&A Psicólogos, as well as international organizations that have begun to implement national MST programs in other Latin American countries such as The Lazos Program in Chile. Access to these programs for at-risk youth is necessary in order to address the underlying factors that are leading them to engage in a life of crime and violence. The cost of crime and violence in Juan's late adolescent years (15-17) is $\$ 502,627$ USD, while the cost of implementing MST at this stage of life is $\$ 3,438$ USD.

Juan's adult years (18+) require substantial investment in order to attempt to address the risk factors in his life and cause a change in his criminal behavior. A shift in policy from the penal system, which in Mexico can become simply an extension of the criminal life on the street, to one more focused on poverty reduction is both necessary and more cost effective. Engaging with adult chronic criminal offenders such as Juan can include behavioral therapy, conditional cash transfer (CCT) programs, or a combination of the two which has demonstrated a more continuous reduction in crime [32]. CCT programs provide financial assistance to poor individuals or families in exchange for fulfilling certain conditions such as health care workshops, school attendance, and vaccination appointments. Until the year 2019, Mexico had an immensely successful CCT program called Progresa/Oportunidades, however it has since been abolished [33]. Currently in Mexico, the organization Jovenes Construyendo el Futuro is implementing a CCT program for job training to connect individuals between the ages of 18 and 29, who do not study and do not work, with companies, workshops, institutions or businesses where they can develop work habits and technical skills to increase their possibilities of future employability. During this program the participants receive a monthly stipend of $\$ 208$ and medical, maternity, and occupational health insurance. While there has not yet been an evaluation of the specific program above, similar CCT programs should be implemented to reduce recidivism and improve outcomes for chronic criminal offenders in Mexico. In Juan's adult years (18+) the cost of his violent actions and criminal activities is $\$ 1,034,847$ USD while the cost of implementing a CCT program is $\$ 365$ USD annually per family.

\section{Discussion}

To our knowledge, this study is the first to evaluate the cost of violence and crime, and potential savings from implementing evidence-based interventions, for a typical criminal offender across various stages of development in Latin America. This story predominantly reflects the realities of young male individuals born into low socioeconomic conditions in Mexico and similar contexts widespread in the region. Results from our cost analysis showed an exponential increase of the cost of Juan's life over time to a total of 
$\$ 1,752,501$ USD by the age of 37 . This exponential and compounding increase highlights the need to implement evidence-based interventions at early stages of development for risk factors that threaten to lead to a life of crime and violence.

While deciding what interventions were necessary for Juan at various stages of his life we concluded that in many stages, a combination of interventions could be implemented to offer a more comprehensive form of support to Juan and his family. During Infancy (0-2), a nurse home visitation program was coupled with Juan's family taking part in a CCT program (Progresa) and during Early Adolescence and Adulthood, CBT was coupled with CCT on a yearly basis. Additionally, since the population that we discuss in this paper is high-risk and may require more resources and time than the average individual, we chose to double the estimated cost of the interventions in our analysis to cover any inaccuracies. Although this may have led our analysis to represent an overcompensation for the cost of interventions, the cost to savings ratio calculated was still 12 dollars saved for every dollar invested.

Ideally, some of these interventions would take place in schools where adolescents are already concentrated. Currently, the Mexican government spends 3.3\% of GDP per year on education, however, the percentage of educational lag in the country has increased from $19.0 \%$ to $19.2 \%$ since 2018 [8, 34]. It is necessary to increase funding towards education to improve access to high quality schools and to decrease school dropout rates-both of which have been shown to reduce juvenile crime [35, 36].

It is crucial to recognize and specifically target the high-risk populations and areas in which crime and violence are concentrated in Mexico. Studies have shown that 75 percent of all crimes are committed by between $5-15 \%$ of individuals $[37,38]$. Further, it has been shown that the majority of crimes in Mexico are committed by those between the ages of 19-35. The known ages of criminal offenders and the availability of geospatial data that details the regions with high prevalence of crime and violence in the country offers an opportunity to direct resources for specifically targeted interventions that can directly focus on those responsible for most of the crimes and violent acts in the country.

Our study is subject to important limitations. As a fictional narrative, Juan's life story has been constructed based on qualitative research derived from the perspectives and personal experiences of researchers, NGO's, and public health officials, and supplemented by survey data of chronic criminal offenders and prisoners in Mexico. Researchers synthesized these perspectives to form a thorough understanding of risk factors, and used them to construct Juan's life story. Since our narrative is descriptive rather than numerical, it is subject to researcher bias and does not have replicability. While our descriptions of Juan's family life and community environment are fictional, they are organic, illuminating, and not without basis in the reality of many young men's lives growing up in disadvantaged conditions in Mexico.

For the quantitative estimations of Juan's criminal offenses and their costs, limitations include that the information used to estimate the frequency of events from Juan's life story was derived from different sources, including private organizations, and public crime and victimization surveys. Data taken from public government sources is subject to underestimation given that over $93 \%$ of all crimes in Mexico are 
left unreported. Therefore, we can assume that our numbers are underestimated, and that the actual frequency of events is likely higher in reality [5]. Another limitation has to do with the costs of preventive interventions. Given that few scientific cost-benefit studies on preventive interventions in Mexico have been published, we had to rely on information provided by the organizations implementing these interventions to estimate the cost of preventative programs. Therefore, the total savings from implementing the aforementioned interventions could differ substantially from what we have reported.

The interventions proposed in this study have been shown to be effective across both developed and developing nations. Therefore, this study is significant not only for Mexico, but also for neighboring Latin and Caribbean American countries that are facing similar levels of crime and violence [11]. Since the penal system in these nations has been shown to be ineffective in preventing crime, it is crucial to shift the focus to policies that focus on prevention of crime and violence-starting at the earliest point of development and continuing throughout the lifetime of at-risk individuals.

\section{Conclusions}

Violence and crime in Mexico (and in the region of Latin American and the Caribbean) have become a public health and development burden on the country, its economy, and the health of its citizens. As long as the Mexican government does not prioritize prevention, and improving living conditions from the earliest stages of life, for those living in poverty, a majority of Mexican children and youth will continue to grow up in environments rife with systematic violations of basic human rights. The lack of access to adequate nutrition, education, safety, and good parenting practices for a large proportion of the Mexican population drives a negative cycle that will continue to have a detrimental effect on subsequent generations with nearly irreversible consequences.

It is imperative that the Mexican government begin to develop and implement a systematic strategy for violence and delinquency prevention based on science, evidence, and epidemiology. With Juan as an example, youth in Mexico are committing crimes at an alarming rate. It is necessary to identify children at risk and provide comprehensive support, prevention and treatment programs for these chronic offenders. Crime control must be based on science, evidence, and data. This requires the continuous monitoring and measuring of programs and interventions, while constantly evaluating the conditions across the country in order to continually adapt to changing conditions.

The current juvenile justice system in Mexico fails to rehabilitate or alter the behavior of delinquent youth. Youth criminal offenders are either incarcerated and sent directly back to the community without resources or, as in the case of Juan, not corrected at all for their actions. It is only through a complete overhaul of violence and crime prevention policies that Mexico can begin to take the necessary steps to creating a safer, healthier, and more prosperous future for its citizens.

\section{Declarations}




\section{Ethics approval and consent to participate}

Not applicable

\section{Consent for Publication}

Not applicable

\section{Availability of Data and Materials}

All data generated or analyzed during the current study are included in this published article [and its supplementary information files].

\section{Competing Interests}

The authors declare that they have no competing interests

\section{Funding}

The authors received no funding for the preparation of this manuscript. The Carlos Peralta Chair of Public Health receives funding from the Fundación Alejo Peralta y Diaz Ceballos IAP, Mexico.

\section{Authors' Contributions}

ACT conceived the idea for the project, led the data collection, analysis, design and editing of the manuscript. RR led the design and drafting of the manuscript, acquired the relevant intervention cost data, and aided in the analysis and interpretation of the data. IDCA led the acquisition and organization of the direct and indirect cost data. IBA and NTDLC aided in the drafting of the manuscript, estimating the costs, and conducting the literature review. All authors read and approved the final manuscript.

\section{Acknowledgements}

The authors wish to thank Victor R. Andrade Carmona and Alejandra Cortés Rodríguez, research associates at the Carlos Peralta Chair of Public Health, Faculty of Health Sciences, Anahuac University Mexico, for their contributions to the research on the cost of violence and crime in Mexico.

\section{Author Information}


Arturo Cervantes Trejo is the Professor and Carlos Peralta Chair of Public Health, Faculty of Health Sciences, Anahuac University Mexico

Roey Ringel is a Research Associate, Faculty of Health Sciences, Anahuac University Mexico

Isaac Deneb Castañeda Alcántara is an Assistant Professor of Public Health, Faculty of Health Sciences, Anahuac University Mexico.

Isaac Baley Amiga is a Research Associate, Carlos Peralta Chair of Public Health, Faculty of Health Sciences, Anahuac University Mexico

Nicole Terrein De La Cruz is a Research Associate, Carlos Peralta Chair of Public Health, Faculty of Health Sciences, Anahuac University Mexico

\section{References}

1. OECD Better Life Index [Internet]. [cited 2021 Oct 12]. Available from: https://www.oecdbetterlifeindex.org/countries/mexico/

2. Felbab-Brown V. Crime and anti-crime security policy in Mexico in 2020 [Internet]. Brookings. 2021 [cited 2021 Oct 14]. Available from: https://www.brookings.edu/blog/order-fromchaos/2021/01/04/crime-and-anti-crime-security-policy-in-mexico-in-2020/

3. Sala de prensa. Noticias [Internet]. Instituto Nacional de Estadística y Geografía. INEGI; 2008 [cited 2021 Oct 12]. Available from: https://www.inegi.org.mx/app/saladeprensa/noticia.html?id= 6655

4. Dijk JJM van, Kesteren J van, Smit P. Criminal victimisation in international perspective: key findings from the 2004-2005 ICVS and EU ICS. Den Haag: Boom Juridische Uitgevers: Wetenschappelijk Onderzoek-en Documentatiecentrum; 2007. 292 p. (Onderzoek en beleid).

5. Encuesta Nacional de Victimización y Percepción sobre Seguridad Pública (ENVIPE) 2021 [Internet]. [cited 2021 Oct 28]. Available from: https://www.inegi.org.mx/programas/envipe/2021/

6. INEGI. Censo de Población y Vivienda 2020. INEGI [Internet]. [cited11 de May 2021]. Available from https://www.inegi.org.mx/programas/ccpv/2020/

7. Los hallazgos más relevantes del estudio son los siguientes: - PDF Descargar libre [Internet]. [cited 2021 Oct 28]. Available from: https://docplayer.es/218869255-Los-hallazgos-mas-relevantes-delestudio-son-los-siguientes.html

8. Medición de pobreza 2018-2020 [Internet]. [cited 2021 Oct 14]. Available from: https://www.coneval.org.mx/Medicion/MP/Paginas/Pobreza_2020.aspx

9. Mexico Peace Index [Internet]. Mexico Peace Index. [cited 2021 Oct 28]. Available from: https://www.indicedepazmexico.org

10. Canada PS. Tyler's Troubled Life [Internet]. 2018 [cited 2021 Oct 28]. Available from: https://www.publicsafety.gc.ca/cnt/rsrcs/pblctns/2016-r005/index-en.aspx 
11. Chioda L. Stop the violence in Latin America [Internet]. Open Knowledge Repository. Washington, DC: World Bank; 2017 [cited 2021Nov1]. Available from:

https://openknowledge.worldbank.org/handle/10986/25920

12. Encuesta Nacional de Victimización de Empresas (ENVE) 2020 [Internet]. [cited 2021 Oct 28]. Available from: https://www.inegi.org.mx/programas/enve/2020/

13. Calculadora IPC - DineroEnEITiempo.com [Internet]. [cited 2021 Oct 28]. Available from: https://www.dineroeneltiempo.com/

14. Kahn C. As Stigma Eases, Single Motherhood In Mexico Is On The Rise. NPR [Internet]. 2013 May 13 [cited 2021 Nov 18]; Available from: https://www.npr.org/sections/parallels/2013/05/14/183674328/as-stigma-eases-singlemotherhood-in-mexico-is-on-the-rise

15. Falcón-Lezama JA, Saucedo-Martínez R, Betancourt-Cravioto M, Alfaro-Cortes MM, Bahena-González $\mathrm{RI}$, Tapia-Conyer R. Influenza in the school-aged population in Mexico: burden of disease and costeffectiveness of vaccination in children. BMC Infectious Diseases. 2020 Mar 20;20(1):240.

16. Salud deteriorada: opacidad y negligencia en el sistema público de salud [Internet]. Salud deteriorada: opacidad y negligencia en el sistema público de salud. [cited 2021 Nov 1]. Available from: https://saluddeteriorada.contralacorrupcion. $\mathrm{mx} /$

17. INEGI. Panorama nacional sobre la situación de la violencia contra las mujeres. :334.

18. Palacio-Mejía LS, Rojas-Botero M, Molina-Vélez D, García-Morales C, González-González L, SalgadoSalgado AL, et al. Overview of acute diarrheal disease at the dawn of the 21st century: The case of Mexico. Salud Publica Mex. 2020 Feb;62(1):14-24.

19. Escobar ER, Gamino MNB, Salazar RM, Hernández ISS, Martínez VC, Bautista CF, et al. National trends in alcohol consumption in Mexico: results of the National Survey on Drug, Alcohol and Tobacco Consumption 2016-2017. Salud Mental. 2018 Mar 5;41(1):7-16.

20. Bergman et al. Delito y Cárcel en México, deterioro social y desempeño institucional. Centro de Investigación y Docencia Económicas (CIDE). 2014 Aug;74.

21. México, primer lugar en abuso sexual infantil [Internet]. 2019 [cited 2021 Nov 22]. Available from: http://comunicacion.senado.gob.mx/index.php/informacion/boletines/45796-mexico-primer-lugaren-abuso-sexual-infantil.html

22. Victor Chávez. Inegi: más de 30 mil niños de México viven en orfanatos [Internet]. El Financiero. 2015 [cited 2021 Nov 22]. Available from: https://www.elfinanciero.com.mx/nacional/inegi-mas-de-30-milninos-de-mexico-viven-en-orfanatos/

23. Benjet C, Borges G, Medina-Mora ME, Zambrano J, Aguilar-Gaxiola S. Youth mental health in a populous city of the developing world: results from the Mexican Adolescent Mental Health Survey. J Child Psychol Psychiatry. 2009 Apr;50(4):386-95.

24. CONAPRED - Noticia: Hay 95 mil niños en situación de calle, según el DIF [Internet]. [cited 2021 Nov 22]. Available from: https://www.conapred.org.mx/index.php?

contenido=noticias\&id=2557\&id_opcion $=\& o p=448$ 
25. Jones NP. Understanding and Addressing Youth in “Gangs" in Mexico. Wilson Center. :30.

26. Le Clercq J. Global Impunity Index 2020 (GII 2020) Impunity Levels in the World. 2020.

27. The Prison Dilemma: Latin America's Incubators of Organized Crime [Internet]. InSight Crime. 2017 [cited 2021 Nov 22]. Available from: https://insightcrime.org/investigations/prison-dilemma-latinamerica-incubators-organized-crime/

28. Olds DL, Henderson CR, Kitzman HJ, Eckenrode JJ, Cole RE, Tatelbaum RC. Prenatal and Infancy Home Visitation by Nurses: Recent Findings. The Future of Children. 1999;9(1):44-65.

29. The life-saving power of perinatal care in rural Chiapas. Compañeros En Salud. Accessed November 5, 2021. https://companerosensalud.mx/blog/olga-and-omar

30. Araujo MC, Dormal M, Grantham-McGregor S, Lazarte F, Rubio-Codina M, Schady N. Home visiting at scale and child development. Journal of Public Economics Plus. 2021 Jan 1;2:100003.

31. HOME [Internet]. paidifundacion. [cited 2021 Nov 16]. Available from: https://en.paidi.org

32. Blattman C, Jamison JC, Sheridan M. Reducing Crime and Violence: Experimental Evidence from Cognitive Behavioral Therapy in Liberia. The American Economic Review. 2017;107(4):1165-206.

33. Parker SW, Todd PE. Conditional Cash Transfers: The Case of "Progresa/Oportunidades." Journal of Economic Literature. 2017;55(3):866-915.

34. Thamara Martínez Vargas. Gasto público en educación. PPEF 2021 [Internet]. Centro de Investigación Económica y Presupuestaria, A. C. (CIEP); [cited 2021 Nov 22]. Available from: https://ciep.mx/gasto-publico-en-educacion-ppef-2021/

35. Machin S, Marie O, Vujic S. Youth crime and education expansion. German Economic Review. 2012 Nov;13(4):366-384. https://doi.org/10.1111/j.1468-0475.2012.00576.x

36. Anderson DM. In School and Out of Trouble? The Minimum Dropout Age and Juvenile Crime. The Review of Economics and Statistics. 2014 May 1;96(2):318-31.

37. Falk Ö, Wallinius M, Lundström S, Frisell T, Anckarsäter $H$, Kerekes $N$. The $1 \%$ of the population accountable for $63 \%$ of all violent crime convictions. Soc Psychiatry Psychiatr Epidemiol. 2014;49(4):559-71.

38. Farrington DP, West DJ. Criminal, penal and life histories of chronic offenders: risk and protective factors and early identification. Crim Behav \& Mental Health. 1993;3(4):492-523.

\section{Figures}




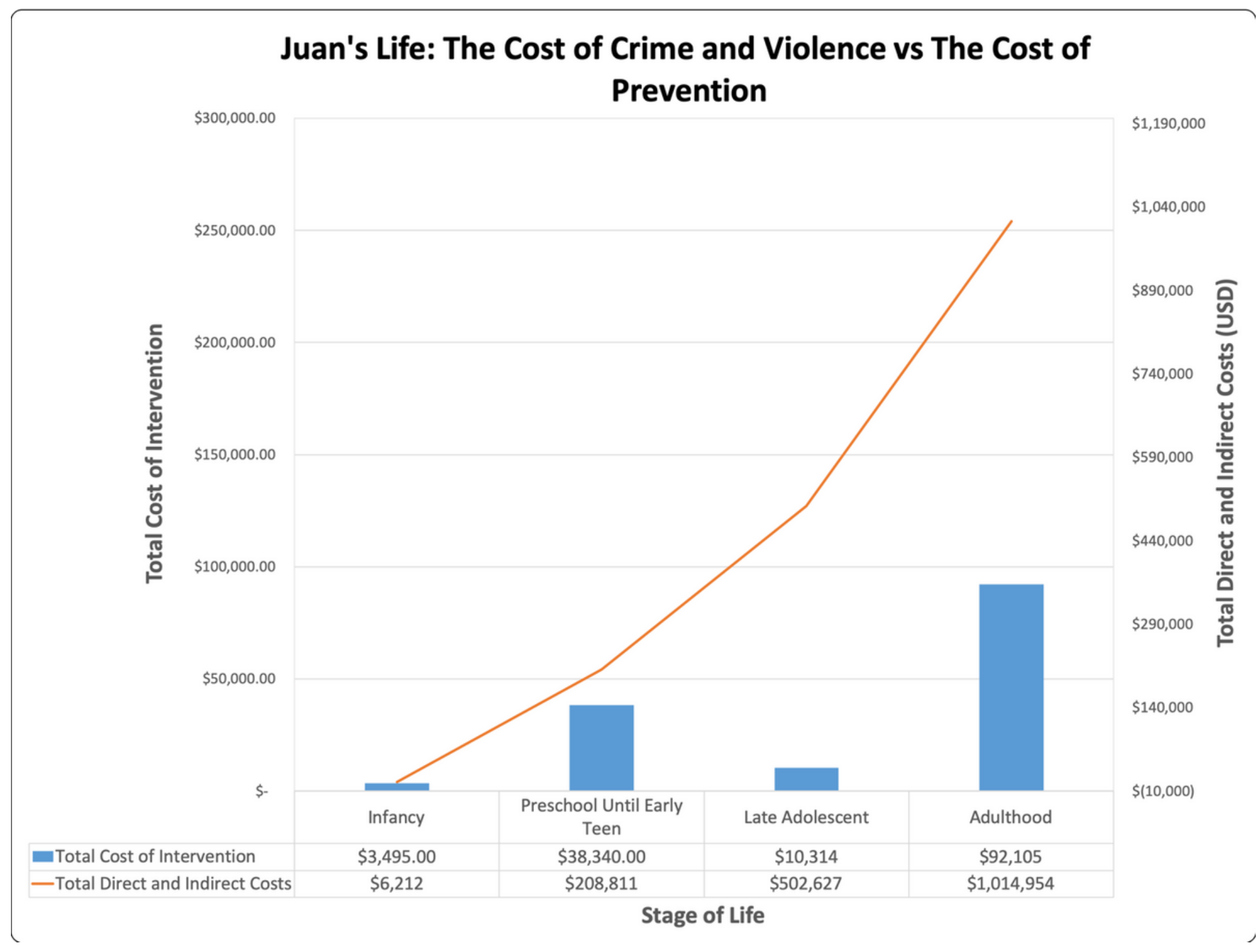

Figure 1

Direct and Indirect Costs vs. Cost of Interventions in Each Stage of Life

\section{Supplementary Files}

This is a list of supplementary files associated with this preprint. Click to download.

- Supplement.docx 